\title{
OPTIMAL TIME AND WAYS \\ OF PRE-VIABLE AND PRETERM LABOURS \\ WITH PREMATURE RUPTURE OF THE MEMBRANES
}

\section{Malanchuk Oleh ${ }^{1}$}

DOI: dx.doi.org/10.30525/978-9934-571-30-5_6

Abstract. In Ukraine, along with one of the lowest birth rates in the world, there is a high prevalence rate of preterm labour, which has no tendency to decrease, and in some regions it is still rising $[3 ; 4 ; 13]$. Causes of preterm births are diverse, but one of the leading cause is the premature rupture of the membranes (breakage of the amniotic sac) (PROM) $[13 ; 27]$. There is information that about $30 \%$ of all preterm labours (before 37 weeks) occurs are complicated by PROM, and rupture of membrances before viability (before 24 weeks) occurs in less than $1 \%$ of all pregnancies [49]. F. Cunningham points out that $30 \%$ to $35 \%$ of all preterm births are caused by PROM [32]. According to various studies, the frequency of PROM widely varies - from 2.7 to $43.9 \%$, and reaches even to $56 \%$ [17]. I. Hösli underlines the fact that prematurity from any case leads up to $75 \%$ of perinatal mortality and about $50 \%$ of all long-term morbidity [37]. PROM is considered to be the responsible for $20 \%$ of all fetal deaths between 24 and 34 weeks of pregnancy [32]. PROM is one of the pressing and serious issues that practical obstetricians solve in the context of preterm birth [1;2]. Dealing with a preterm pregnancy with PROM a physician should solve a number of complicated tasks: how long it is necessary to prolong the pregnancy in order to give the possibility a woman to carry it out to the full term of gestation, to prevent the respiratory distress syndrome (RDS) in newborn premature infants; what tactics of clinical management should be chosen and in what way it is a rational way to make a birth; how to avoid the inevitable development of the infection and which antibacterial drugs should be prescribed. In available scientific literature nowadays, there

\footnotetext{
${ }^{1}$ Candidate of Medical Sciences, Obstetrician-Gynecologist, Deputy Chief Physician of Medical Work, Kyiv Perinatal Centre, Ukraine

(C) Malanchuk Oleh
} 
is no consensus on the duration of the expectant management tactics of antenatal care (ANC) in the period of 22-28 weeks' gestation and the way of giving birth by the women with PROM. A differentiated approach to the anticipatory tactics of pregnancy with PROM in patients undergoing very early preterm labour (VEPL) has been developed and implemented in clinical practice. Recommended optimized pregnancy and childbirth tactics in women during the gestation period of 22-28 weeks complicated by PROM, reduces the incidence of intragastric hemorrhage (IGH) and necrotizing enterocolitis (NEC), and the gestation period of 22-25 weeks does not affect these rates. Represented way of ANC and birthchild does not affect the viability of newborns in the term of 22-25 weeks' gestation. Among the problems of modern obstetrics, PROM keeps one of the main places in preterm labour. High relevance of this is conditioned not only by considerable prevalence but also by social significance in modern conditions. PROM occurs in $30-40 \%$ of preterm labour $[1 ; 13 ; 14 ; 22]$. Complications for the fetus and the newborn are primarily determined by the term of pregnancy, which PROM causes. There is no generally accepted classification of premature births, but in Ukraine, since 2006, when the transition to perinatal age criteria has been recommended by WHO, premature births are divided into: VEPL (22-27 weeks of pregnancy), early preterm labour (28-33 weeks), preterm labour (34-36 weeks). The proportion of specific gravity of these categories of preterm labour is approximately $15 ; 35$ and $50 \%$ respectively [8]. In the structure of the causes of preterm labour, PROM occupies one of the main places not only in Ukraine but also throughout the world [22; 23]. PROM is one of the most pressing and serious issues that practical obstetricians solve in the context of miscarriage, it occurs in $30-40 \%$ of preterm births [24] and $10-12 \%$ in spontaneous deliveries [31]. Preterm labour is the most common cause of neonatal morbidity and mortality. The earlier the pregnancy is interrupted, the more negative for the newborn waiting and the long-term results. Premature delivery at the term of 22-27 weeks' gestation leads to increased morbidity and disability of children. Perinatal mortality with PROM increases from 6.6 to $18-20 \%$ [24; 31]. In each third case, the cause of neonatal mortality associated with PROM with preterm labour in the period of 22-28 weeks' gestation is a variety of complications, among which the biological immaturity of organs, and especially the brain and lungs, sepsis $[33 ; 47]$. 


\section{Introduction}

The main theme of the article is one of the most urgent ways of treatment and tactics of management of preterm pregnancy with premature rupture of membranes in the period of 22-28 weeks' gestation. So, the chief aim of the present study is to investigate the topical problem of PROM and to describe the possible tactics of ANC with PROM in the period of 22-28 weeks' gestation.

To achieve the afore-mentioned goal we establish the following tasks: 1) to study the main tactics of ANC, their types and risks; 2) to examine prognosis for labours with PROM in the period of 22-28 weeks' gestation; 3) to develop optimal ways of labour induction and its management; 4) to focus on main directions in therapy of pregnant women with PROM; 5) to characterize the possibilities to use tocolytic medications to prevent contractions and the beginning of labour; 6) to describe existing ways of sealing amniotic membranes after PROM.

\section{Main tactics of ANC, their types and risks}

The probability of independent birth activity development with PROM depends on the period of pregnancy. During the first day labours begin in $26 \%$ of the weight of the fetus 500-1000 g; in 51\% - 1000-2500 g; in $81 \%-$ more than $2500 \mathrm{~g}$ [15].

In the case of preterm labour and PROM, it is necessary to choose the tactics of ANC. Currently, in Ukraine, the tactics of assistance in the case of PROM is regulated by the Order of the Ministry of Health № 782 of December 29, 2005 [8]. During the period of pregnancy from 24 to 34 weeks, it is rational to use the anticipatory tactic, which allows achieving the maximum probable degree of maturity of the fetal lungs with a minimum risk of ascending infection [15].

Having studied the resources of MEDLINE and Cochrane Library for the period of 1980-2010, it was established that there is no question of induction of premature births in the PROM. In many publications, reviews devoted to the pre-induction / induction of childbirth with PROM and preterm labour, it is emphasized that the research continues, as there is no evidence base for the findings. Thus, the problem of the expectant management, active expectant management or active tactics of PROM and premature labours is relevant to this day [46]. 
Tactics of prolongation of pregnancy depends on the term of gestation. At the age of 28-31, each week has its value, at 32-34 weeks, the value is every 2-3 days; after 34 weeks, the expectant management tactics is unjustified [20].

In the case of preterm labour and PROM it is necessary to assess: 1) the risk of expectant management tactics (fetal risk - premature, neonatal sepsis, pulmonary hypoplasia, RDS, contractures, umbilical cord compression; and woman's in childbirth risks - premature detachment of normally placed placenta, chorioamnionitis, sepsis, hypotonia, uterus, fever and endometritis in the postpartum period); 2) the risk of active expectant management tactics (induction of labour); 3) the risk of active tactics (cesarean section) [27; 47].

Duration of expectant management tactics at PROM in the preterm pregnancy is determined by the term of gestation, the general condition of the mother and the fetus, the quantity and dynamics of the volume of amniotic fluid, the presence of clinical and labouratory signs of chorioamnionitis [11].

In 2010, in the Cochranov Library, results of the only comparative analysis between the labours during the expectant management and active tactics of women with PROM in the period from 25 to 36 weeks of gestation were published.

No difference was found in the incidence of neonatal sepsis, RDS in newborns, perinatal mortality, neonatal morbidity, IGH, necrotic enterocolitis depending on the tactics of ANC. The increased number of endometritises after delivery by cesarean section was established [21].

At the term of pregnancy of 28-34 weeks, the risk for labour is the amount of amniotic fluid in the PROM, which remained in the uterus. According to the index of amniotic fluid $<5$, a high frequency of cesarean section delivery; a low score according to the Apgar score was observed in newborns at the first minute, high mortality at the first week after birth [50].

\section{Prognosis for labours with PROM}

The prognosis of childbirth with PROM depends on the duration of an anhydrous period. R. Frenette et al. [50] examined pregnant women at the 24-33 weeks' pregnancy term. They concluded that during the latent anhydrous period $>48$ hours the incidence of newborns was lower compared to the latent anhydrous period $<24$ hours. Expectant management tactics for PROM against prematurity reduces the morbidity of a newborn from 
prematurity without increasing infectious complications in the mother and fetus, but the risk of a significant infection remains high [50].

At the same time, research has found [23] that the infection expands after a 72-hour anhydrous period. Positive in active tactics is the reduction of infectious complications in a mother and a child [26].

There are several contraindications to the expectant management tactics - chorioamnionitis, complications of pregnancy, which requires longterm delivery. For example, pre-eclampsia / eclampsia, placental abruption, bleeding in placenta previa; decompensated mother's condition; decompensated fetal condition; significant oligohydramnios (amniotic index $<3 \mathrm{~cm}$ ) for 3 days; development of independent labour activity (contractions with a frequency of 4 for 30 minutes and a duration of 30-40 s or more, a shortening of the cervix by $80 \%$ of the original length, opening of the cervix $\geq 3 \mathrm{~cm}$, meconial water Chorioamnionitis is an indication for rapid birth $[7 ; 8 ; 54]$.

At the term of gestation from 22 to 34 weeks at a satisfactory state of the fetus and the pregnant woman, a sufficient amount of amniotic fluid, and in the case of cessation of amniotic fluid breaking, pregnancy can be prolonged until the end of the term. Pregnancy for 1-3 weeks (rarely for a longer period) can be prolonged with continuous breaking of amniotic fluid, maintaining the level of amniotic fluid and the index of amniotic fluid > $3 \mathrm{~cm}$, satisfactory state of the fetus and mother, the absence of inflammatory process and the activation of labour [15].

With a significant reduction in amniotic fluid (amniotic index $<3 \mathrm{~cm}$ ), regardless of the duration of the anhydrous period, the risk of squeezing the fetus in the uterus increases with the development of facial skeletal abnormalities, contracture of the extremities, and hypoplasia of the lungs arises. Consequently, the complications for the fetus during PROM depend on the term of gestation, the number of leaked amniotic fluid and the duration of the anhydrous period [48].

P. Frenette et al. [50] proved that during the period of 24-37 weeks' pregnancy for anhydrous period more than 48 hours the morbidity of newborns was less than that for anhydrous period up to 48 hours. It is concluded that the expectant management tactics of PROM and premature pregnancy may reduce the incidence of newborns morbidiry from premature birth with minimal risk of complications of infectious genesis for a mother and a fetus in inpatient treatment [50]. 


\section{Induction of labour and its management}

Earlier, the terms pre-induction cervix uteri preparation and induction of labour (amniotomy + use of oxytocin) were used separately. Nowadays the term induction of labour includes the preparation of the cervix uteri (using prostaglandins and laminaria). Most researchers believe that induction is necessary and mandatory in a biologically immature cervix uteri $[34 ; 56]$.

The problem of labour induction with PROM on the background of pregnancy at 22-28 weeks in obstetrics remains unresolved and controversial. Induction of labour in preterm pregnancy is a matter of discussion, since it is necessary to examine carefully the risk of prematurity, PROM, duration of the anhydrous period, oligohydramnion, and others [12; 49].

There are different methods of preparing the cervix unteri for delivery: non-medicated (finger abruption of the fetal membranes, sexual life), instrumental (methods of acupuncture, massage, intranasal electrostimulation, electrostimulation of the mammary glands, etc.), local application of prostaglandins, introduction of laminaria, prescribing of spasmolites, etc. There is an evidence base only on the local use of prostaglandins and osmotic dilators (laminaria).

Prostaglandins is a group of lipid physiologically active substances that contain a 20 -atomic carbohydrate chain. They are formed enzymatically from essential fatty acids (in particular, arachidonic acid). They are called tissue hormones. According to the orders of the Ministry of Health of Ukraine, prostaglandins are used in the case of an immature cervix uteri at 41 weeks' pregnancy or more. Possibly their use in programmable deliveries in high-risk pregnant women (non-treatable preeclampsia, extragenital pathology, antiphospholipid syndrome, dead fetus, etc.). Advantages of using prostaglandins are the reduction of the frequency of weakness of labour activity, surgical iprocedures and blood loss in delivery.

Predominately for this purpose, prostaglandin E2 (prostyn-gel) is used. It affects the contractile activity of myometrium as a result of expression of subtypes of receptors EP1, EP2, EP3 and EP4 with different localization and expression [16].

The preference should be given to intracervical administration of prostaglandin E2, a dose of $0.5 \mathrm{mg}$. Intravaginal dose $-1 \mathrm{mg}$ in the posterior vault. In 6-12 hours, a repeated dose can be used. In the absence of the effect of endocervical administration, the drug is used vaginally twice $-1 \mathrm{mg}$ at intervals of 6 hours. The maximum dose is $3 \mathrm{mg}$ in 4 administrations. 
Adverse reaction of prostaglandins: nausea, vomiting, diarrhea, headache, hyperthermia syndrome, dry mouth of the oropharynx, pharyngitis, laryngitis, bronchospasm, paresthesia, tremor, drowsiness, visual impairment (diplopia), tinnitus, hypertension, tachycardia. In the event of adverse reaction, delivery ends with a cesarean section.

The risk of labour induction with intravaginal administration of prostoglandin E2 is: a pathological prelinarial period, an unproductive labour activity with insufficiently mature cervix uteri, hypertonic myometrium, incoordination of a labour activity, uterine rupture, premature abruption of a normally placed placenta, fetal distress of the fetus, especially when the gel is ingested cavity of the uterus. In preterm pregnancies, especially with PROM, complications often occur in the fetus [12;22].

The risk of labour induction with prostaglandin $\mathrm{E}_{2}$ in multipara is somewhat different from its use in the primipara: less oxytocin and amnionotomy were used, in 57\% women the labour started within 12 hours, wherein in $78 \%$ of women delivered per vias naturalis, in $22 \%$ by cesarean section, in $5-6 \%$ was hyperstimulation of the uterus, increased percentage of fetal distress in the process of labours [9].

Other prostaglandins that are used in obstetrics are $\mathrm{E}_{1}$ (misoprostol, cytotec) and $\mathrm{F}_{2 \dot{\alpha}}$ (enzaprost). Mizoprostol can not be recommended to be used before the labour due to severe adverse reaction, such as an effect on the upper uterine segment (danger of hypertone). The drug has not yet been certified in Ukraine [56]. Prostoglandin $\mathrm{F}_{2 \dot{\alpha}}$ (enzaprost) can not be recommended to be used for labour preparation, since its action is directed to the upper uterine segment, therefore, it is used only in the active phase of the first period of labour. Thus, only the drugs of prostaglandin $E_{2}$ can be used to prepare for labours.

Osmotic dilators - natural and artificial laminaria can be used for labour induction. The basis of their tissue is the presence of polysaccharides, in which the dried laminaria quickly absorbs moisture from the tissues surrounding and increases in size. Due to hygroscopicity, after 3-4 hours after insertion, laminaria swells in diameter of appr. one-half inch and reaches a maximum of swelling in the first 4 to 6 hours, 3-5 times up to 24 hours. Because it is a gradual process, a patient rarely notices pain [42]. The consistency of the laminaria from the dense turns into a much softer and resembles rubber. An important positive feature is that with the expansion of the cervical canal up to $9-12 \mathrm{~mm}$, the length of the laminaria remains 
unchanged. Relative contractions for the use of laminaria are colpitis, cervicitis, operated uterus, practically there are no absolute contractions. However there are some disadvantages of using laminaria - the risk of infectious complications, technical difficulties for the doctor, pain for the patient, complete clinical effect comes in 16-24 hours. Reviews of laminaria dilator use have reported infectious morbidity, endometritis, fetal sepsis, septic shock, and anaphylaxis [39; 40; 41 cited ob 42, 43]. Advantages of using laminaria - virtually no adverse reactions, high efficiency, relatively low price. According to the data $[12 ; 14]$, it is allowed to find laminaria in the cervix channel up to 48 hours. Synthetic laminaria (dilapan) is made on the basis of polyacrylonitrile hydrogel. In Ukraine, the drug is currently not certified.

\section{Main directions in therapy of pregnant women with PROM}

In the clinical observation of pregnant women with PROM, three main directions of their management are important: prevention of RDS, tocolytic and antibacterial therapy.

RDS ranks first in the morbidity and mortality of newborn babies with a gestational period of 22-27 weeks, the main cause of which is the immaturity of the lungs and their lack of readiness for adequate gas exchange. Prevention of RDS in this period is ineffective, since pneumocytes of the second order begin to produce surfactant only after the $27^{\text {th }}$ week of pregnancy $[14 ; 18]$. Surfactant - a heterogeneous mixture of lipids and proteins that cover the alveoli, promotes their opening by inhalation and prevents collapse when exhaled.

In this category of premature newborns, is extremely high perinatal mortality, most often occur such remote effects as pathology of the central nervous system, such as cerebral palsy; delayed neuropsychecal development; pathology of the respiratory tract (bronchopulmonary dysplasia); blindness and deafness [6].

The use of antenatal corticosteroids has shown unquestionable benefits. The antenatal course of steroids aimed at improving the postnatal function of the lungs, namely stimulation of the synthesis and secretion of endogenous surfactant, increased compliance, and increased functional residual capacity (FRC) of the lungs. The change in FRC and compliance improve pulmanory gas exchange and perfusion of the lungs and, as a consequence, reduce the child's need of additional oxygen [5]. 
Antenatal course of steroids ( $24 \mathrm{mg}$ betamethasone or $24 \mathrm{mg}$ dexamethasone within 48 hours) significantly reduces neonatal mortality by $31 \%$, RDS frequency by $34 \%$, IGH by $46 \%$, necrotizing enterocolitis by $54 \%$, early sepsis during the first 48 years of life - by $44 \%$ and the need for artificial pulmonary ventilation - by $20 \%$ [53].

Numerous experimental studies have shown that in preterm newborns, RDS develops due to lack of surfactant in immature lungs. A small amount of surfactant is produced with the participation of methyltransferase from 22-24 weeks of fetal life. After birth, under the influence of hypoxia, its production by this manner is ceased. Synthesis of surfactant with the participation of phosphocholintransferase begins within the $5^{\text {th }}$ week of fetal life. This system is more resistant to acidosis and hypoxia.

The effect of using antenatal steroids during pregnancy in the gestation period of 24-28 weeks is somewhat different: less effective reduction of the RDS frequency and severity, but significantly reduction of the incidence of necrotizing enterocolitis (41\%) and improves the child's response to subsequent treatment using surfactant (59\%) [53].

However, despite the proven effectiveness of antenatal course of steroids and the use of this technique for more than 20 years, many questions regarding the duration of the effect, safety and benefit of refresher courses of treatment of antenatal steroids remain unresolved until now.

During clinical studies, it was found that the maximum effect from the antenatal course of steroids was observed in children born at least 24 hours after the beginning of the course and within 7 days after completion. Clinical studies and in vitro studies have shown that the steroid induced biochemical effects significantly decreased after 7 days of completion of the course, while structural changes in the lungs continued. Therefore, it was assumed that the antenatal courses of steroids every 7-10 days before the birth of a child will ensure the reduction in the incidence of RDS and neonatal mortality. Several complications of long-term postnatal use of steroids in newborns have been described, which included delayed development, increased incidence of infections, development of systemic hypertension and left ventricular hypertrophy, inferiority of the adrenal glands, violation of the myelination process, as well as negative consequences of neurological development of children.

In the study of the effects of refresher course of treatment of antenatal steroids on the reduction of neonatal mortality and morbidity (RDS, 
chronic lung disease, IGH of III-IV grades) the difference between the incidence of RDS development in children receiving 1.2 and $\geq 3$ antenatal steroids courses was not established in comparison to one course. The increase in the frequency of negative consequences and death in the gestation period of 36 weeks has been established: thus, in children born at the 25-27 weeks' gestation and received 3 antenatal courses, mortality was $26 \%$. It significantly exceeded the incidence of mortality in children who received one course (13\%) and two courses (11\%). Researchers have proved that there is no difference in the rate of development of IGH of III-IV grades, necrotizing enterocolitis, open arterial duct (patent ductus arteriosus) and retinopathy, depending on the number of antenatal steroid courses, although the studies clearly demonstrated a significant prolonged suppression of adrenal function in children receiving $\geq 3$ courses of antenatal steroids $[5 ; 29 ; 51]$.

Nowadays, questions that concern not only the pathogenic effect on the fetus of intramuscular injections of glucocorticoids, but also the prolonged use of synthetic glucocorticoids for the correction of autoimmune and endocrine disorders in the event of miscarriage are widely discussed. It has been proved that synthetic glucocorticoids penetrate freely through the placenta, activate the hippocamp- hypothalamic-adrenal system of the fetus, and cause inhibited synthesis of proteins and nucleic acids (DNA and RNA), thus affecting cell enlargement and cell division delay. This hypothesis confirms that the birth of children with low body weight and the manifestations of morphofunctional immaturity in full-term pregnancy is characteristic of women who have used glucocorticoids durably. These issues are debated and need further study [44].

According to the theory, prolonged use of corticosteroids can lead to immunosuppression, and as a consequence - to the increase in the frequency of severe infections in both mothers and newborns. Investigation of children 24-34 weeks' of gestation after refresher courses of treatment with antenatal corticosteroids revealed an increase in the frequency of chorioamnionitis in 5 times, endometritis - in 3.61 times, early neonatal sepsis 5 times, neonatal mortality -2.92 times. And with it, the frequency of sepsis as the main cause of neonatal mortality was lower in the group of newborns who received an antenatal course of steroids [45; 53].

Some clinical studies have found a negative effect of refresher courses of antenatal corticosteroids to physical (intrauterine growth retardation) and 
further psychomotor development of children [54]. If the decision about refresher courses of corticosteroids should be born in mind that the benefits of 2-3 courses if long threatened abortion in up to 32 weeks is proven, and the negative impact on the physical development of the fetus appears in the case of a $\geq 4$ courses. Also one should remember that there is effective and safe intramuscular introduction for a course of $24 \mathrm{mg}$ betamethasone or dexamethasone for 48 hours, unacceptable use of the reduced rate, such as $24 \mathrm{mg}$ in 24 hours) or intravenous introduction of corticosteroids to accelerate its action [53].

According to the Order of the Ministry of Health of Ukraine (No. 624 of November 3, 2008) [7], the RDS prophylaxis is carried out from the $24^{\text {th }}$ to the $34^{\text {th }}$ weeks: under the threat of preterm labour, dexamethasone is injected intramuscularly by $6 \mathrm{mg}$ every 12 hours (on course $24 \mathrm{mg}$ ) or betamethasone $12 \mathrm{mg}$ every 24 hours ( $24 \mathrm{mg}$ course). It is not recommended to conduct refresher courses for the RDS prevention. Corticosteroids are not used in the presence of clinical manifestations of severe infection. The efficacy of betamethasone and dexamethasone is identical. Data on the advantages and disadvantages of each of these drugs are controversial and require further study $[25 ; 29]$.

The prescription of glucocorticoids to accelerate the maturation of the fetal lungs makes sense if delivery is expected within the next few days. Contraindications to therapy are gastric ulcer and duodenal ulcer, insufficiency of blood circulation of the III degree, endocarditis, nephritis, active form of tuberculosis, severe forms of diabetes mellitus, osteoporosis, severe form of gestosis [22].

\section{Using tocolytic medications}

\section{to prevent contractions and the beginning of labour}

The feasibility of using tocolytics is rather dubious and controversial, since labour pains can be a consequence of hidden chorioamnionitis, so the inhibition of a labour activity can contribute to the spread of infection. Tocolytic medications can stop the progression of labour in a short period of time, but there is a danger of their toxic effects on the mother's body in the form of hypotension, tachycardia, fluid retention in tissues $[19 ; 20]$. From the other hand as it is proved, once labour has already started, using tocolytic medications to stop it has not been shown to help, and thus can not be recommended [49]. 
It has not been proved yet that tocolysis improves perinatal outcome. After stopping labour, one can get enough time to use antenatal steroids, transport a woman to the perinatal center, where there is a powerful resuscitation of the newborns. After the $34^{\text {th }}$ week of pregnancy, it is inappropriate to prescribe tocolytic drugs in general, as children are born viable, and the risk of complications of such therapy is significantly superior to its use. A part of the obstetricians do not use tocolysis at all with PROM and premature pregnancy, and the rest of them applies only at the risk of preterm labour, with therapy being prescribed only for 48-72 hours to prevent RDS, then the tocolytics are cancelled and continue to monitor. If the labour activity has begun, it is not blocked.

Tocolysis sympathomimetic - hexoprenaline (hexoprenaline). Its main pharmacotherapeutic effect - suppresses contraction activity of the uterus. This is a selective $\beta 2$-sympathomimetic, which reduces the frequency and intensity of uterine contractions; suppresses spontaneous, as well as oxytocin-induced labour contractions; during labour normalizes extremely strong or irregular contractions; under the action of hexoprenal, premature contractions in most cases stop, which allows to continue pregnancy; has a negligible effect on cardiac activity and blood flow of a pregnant and her fetal. It is excreted in the urine, a small part is excreted with bile in the form of complex metabolites.

At the beginning of treatment, tocolysis begins with the injection of 10 micrograms intravenously. To do this, $10 \mu \mathrm{g}$ of hexoprenalin is dissolved in $10 \mathrm{ml}$ of sodium chloride or glucose, injected slowly for 5-10 minutes. Then the intravenous infusion is continued at a rate of $0.3 \mu \mathrm{g} / \mathrm{min}$, it is possible to inject the drug at a rate of $0.3 \mu \mathrm{g} / \mathrm{min}$ and without prior intravenous injection; inject intravenously drip $(20$ drops $=1 \mathrm{ml})$. In case of prolonged tocolysis, a dose of $0.075 \mu \mathrm{g} / \mathrm{min}$ is recommended. It is not recommended to use oral tablet tacrolytics for supportive therapy after successful treatment of preterm labour $[3 ; 20]$.

In two hours after the onset of tocolysis, it is necessary to confirm the diagnosis of preterm labour, if it progresses, tocolysis is discontinued.

Adverse reactions and complications in the use of tocolysis: dizziness, light tremor of the fingers, anxiety, increased sweating, tachycardia, headache, nausea, vomiting; isolated cases of heart rhythm disturbances (ventricular extrasystoles), cardialgia, difficulty in breathing; the level of sugar in the blood, especially in diabetes mellitus, increases as a result of 
hyperglycemic action of the drug; swelling may occur in patients with a tendency to fluid retention in the tissues; possibly reducing the intensity of intestinal motility; in newborns may occur hypoglycemia and acidosis, bronchospasm, anaphylactic shock. Contraindications for use: hypersensitivity to the drug, thyrotoxicosis, cardiovascular diseases (heart rhythm disturbances accompanied by tachycardia, myocarditis, mitral valve defects and aortic stenosis, arterial hypertension, coronary heart disease), severe liver and kidney diseases, closed-angle glaucoma, uterus bleeding, premature detachment of the placenta, intrauterine infections, I trimester of pregnancy, period of lactation [4].

The need to reduce the dose and duration of taking $\beta$ - adrenoceptor agonists motivates to look for alternative drugs to treat the threat of preterm labour [8].

Tokolysis is an antagonist of oxytocin - atosiban (tractocil, tractocile). The main pharmacotherapeutic effect is the competitive antagonist of human oxytocin at the receptor level. It is a synthetic peptide, which, by binding to the oxytocin receptors, reduces the frequency of uterine contractions and reduces the myometrium tone that suppresses the contractility of the uterus and also binds to vasopressin receptors. In the case of development of preterm labour, atosiban at the recommended dose suppresses uterine contractions, which begins almost immediately after its introduction. Within 10 minutes, the contractile activity of myometrium is significantly reduced, maintaining a stable functional uterus (less than 4 cuts per 1 hour) for 12 hours. Discharged with urine, feces, breast milk. Tractocil is used to slow the labour activity in case of threat of preterm delivery in pregnant women in cases where regular uterine contractions last for at least $30 \mathrm{~s}$ and frequency more than 4 times in 30 minutes; with the expansion of the cervix from 1 to $3 \mathrm{~cm}$ (0-3 cm for women who gave birth for the first time), smoothing more than $50 \%$; in women over 18; pregnancy period from 24 to 33 full weeks; normal heart rate in the fetus. Tractocil should not be used in cases where the pregnancy is less than 24 or more than 33 full weeks; PROM during pregnancy for more than 30 weeks; intrauterine retardation of growth and abnormal fetal cardiac rhythm; prenatal uterine bleeding; intrauterine fetal death; suspicion of intrauterine infection; placenta previa; placenta detachment; hypersensitivity to the active substance or excipients in the anamnesis.

In order to achieve the exact dosage of the drug, an infusomat must be used. Tractocil is injected intravenously into three consecutive stages. The 
first stage - solution for injection is administered at an initial dose atosiban of $6.75 \mathrm{mg}(0.9 \mathrm{ml})$ for $1 \mathrm{~min}$. The second stage - the concentrate is dissolved either in a $0.9 \%$ solution of sodium chloride, either in a solution of Ringer-lactate, or in a 5\% solution of glucose. From a container of $100 \mathrm{ml}$ take $10 \mathrm{ml}$ of the appropriate solution is taken and poured out. $10 \mathrm{ml}$ of the tractocil concentrate ( 2 vials of $5 \mathrm{ml}$ ) is added to the solution to obtain a concentration of $75 \mathrm{mg}$ of atosiban in $100 \mathrm{ml}$. Loading infusion is carried out by administering the prepared solution at a rate of $24 \mathrm{ml} / \mathrm{h}$ (that is $18 \mathrm{mg} / \mathrm{h}$ ) for 3 hours under proper medical supervision in the obstetric department. The third stage - is carried out in the way of a long-term (up to 45 hours) infusion of a concentrate in a low dose of $8 \mathrm{ml} / \mathrm{h}$, equal to a dose of $6 \mathrm{mg} /$ hour. The duration of treatment should not exceed 48 hours. The full dose of the drug for the entire course of therapy should not be more than $330 \mathrm{mg}[4 ; 14]$.

In clinical studies, possible adverse reactions in the body of a mother have been described, but not detected in newborns. As an antagonist of oxytocin, atosiban theoretically can enhance uterine relaxation and trigger postpartum uterine bleeding, so it is necessary to evaluate constantly blood loss at labour. Adverse effects from the gastrointestinal tract happen very frequently - nausea. Hyperglycemia, headache, dizziness, tachycardia, hypotension, blood flushes, vomiting, and reaction at the injection site occur as well. Sometimes - insomnia, itching, rash, allergic reactions. Compared with $\beta$-mimetics and calcium channel blockers, atosiban has few adverse effects, but tocolysis by nifedipine is interspersed with a significant recession in RDS compared to atosiban [30].

Tokolysis with an inhibitor of cyclooxygenase - indomethacin is ffective from 20-22 weeks' of gestation and is used up to 32 weeks of gestation [21].

Medication is started with $50-100 \mathrm{mg}$ rectally or per os, then $25 \mathrm{mg}$ every 6 hours (no more than 48 hours). Possible adverse reactions to the body of a mother and a fetus are described. In a mother - nausea, reflux, gastritis. In a fetus - premature closure of the arterial duct, oliguria, oligohydramnios (for prolonged use in a period of more than 32 weeks). Contraindications to use - impaired coagulation and compromised liver function, bleeding, ulcer disease, asthma, hypersensitization to aspirin.

Tocolysis blocker of calcium channels - nifedipine. The advantage of prescribing nifedipine is a low frequency of adverse reactions in the 
mother: hypotonia, tachycardia, nausea, headache, dizziness. Nifedipine is prescribed at a maximum dose of $160 \mathrm{mg}$ / day: $10 \mathrm{mg}$ sublingual, repeating the dose every 20 minutes (for 1 hour $40 \mathrm{mg}$ ), then every 4 hours for $20 \mathrm{mg}$ to 48 hours [10].

This medication is recommended to be used in isolation, as together with magnesium sulfate it is possible to cause side effects on the cardiac and pulmonary systems. Blockers of calcium channels do not need to be prescribed to patients with multiple pregnancies, hypertension, heart disease, because they can cause myocardial infarction.

Tocolysis of magnesium sulfate. In most countries, magnesium sulfate is not registered as a tocolytic agent, but is used in pregnant women with hypomagnesaemia, preeclampsia, has neuroprotective effects for the mother and the child $[52 ; 55]$.

Adverse reactions of intravenous administration to the mother: bradycardia, diplopia, blood flushing to the face, hypotension, headache, suppression of the cardiovascular system and central nervous system, uterine atony, hypothermia, secondary hypocalcemia with signs of secondary tetany. The drug is not recommended for women with myasthenia. The use of magnesium sulfate for the purpose of neuroprotection at preterm labour before the 32nd week of pregnancy as a whole does not affect infant mortality, but significantly reduces the incidence of cerebral palsy and severe motor dysfunctions [44; 55; 59].

Using of magnesium sulphate is often discussed on the safety for the fetus. It has been scientifically proven that magnesium sulfate not only has no aparent tocolytic activity, that is, it does not prevent premature labours, but almost 3 times increases postnatal mortality due to vasculitis in newborns, and motor dysfunctions are detected in children of 2 years. In recent years, the drug is not recommended for tocolysis as a first-line drug.

A Cochrane review showed that transvaginal amniofusion in deliveries at the term of 26-36 weeks' pregnancy and PROM did not differ significantly in the Apgar scale and neonatal mortality among groups of women who were prescribed or were not prescribed (by cesarean section delivery) [36].

In other study, transvaginal amniofusion was performed with the expectant management tactics of ANC in the term of 22-34 weeks' gestation with PROM. It was shown that the risk of postnatal death of children from pul- 
monary hypoplasia was the same in the groups where transvaginal amniofusion was either conducted and not [60].

Mentioned techniques can be used to close a small opening after amniocentesis (which is a topical problem nowadays, since the frequency of amniorrhexis after fetoscopy is 5-30\%), but not to restore the integrity of fetal membranes with their spontaneous rupture (the defect is more significant) $[54 ; 61]$.

\section{Sealing of amniotic membranes after PROM}

Nowadays for sealing the damaged amniotic membranes after PROM For can be used: amniopatch - intramammary administration of fibrinogen solution, fibrin glue - intracervical administration of fibrin glue, amniograft - endoscopic overlaying of collagen lining.

Tisseel (Baxter Co, Lessen, Belgium) - a drug containing thrombin, fibrinogen, aprotinin, calcium, cryoprecipitate, it has a greater capacity to restore the integrity of fetal membranes than thrombocytes [35].

Laser welding (Nd: YAG) to seal ruptures of fetal membranes in vitro because of the high risk of damaging impact of the laser energy can hardly be applied. On models tested in vitro methods of suturing with prolene surgical suture - applications of synthetic polymer Synthaseal (Promethean Surgical Devices, Mendon, MA) [35].

The application of autologous tromboconcentrate (cryoprecipitate) contains fibrinogen, fibronectin, growth factors PDGF, TGF, factor von Willebrand, factors VIII and XIII) and entitled "Amniopatch", which can restore amniotic sac in case of iatrogenic injury (amniocentesis). Five procedures were performed, in four of them amniopatch allowed to prolong the pregnancy to the term of the fetus viability $[28 ; 58]$.

The application of fibrin glue for patching the membranes in the second trimester of pregnancy for the purpose of treatment of oligohydramnios and prevention of pulmonary dysplasia in the fetus is not carried out nowadays. In the special medical literature, there are few publications, which describe a small number of events when the membranes were patched in the case of PROM [38]. Recently, for patching the membranes were used intracervical injections of fibrin into amniotic fluid. In some cases, the procedure contributed to an increase in the number of amniotic fluid $[38 ; 57]$. These studies require further examination of pregnant women for the evaluation of neonatal complications and can not be recommended for general practice yet. 


\section{Conclusions}

In conclusion, it may be said that during pregnancy of 22-28 weeks' gestation and PROM, an expectant management tactics of ANC during 5 days with further labour via cesarean section was developed. The efficacy of the developed management is confirmed by immunological and morphological placental studies, examination of the newborns health in the early neonatal period.

An indication for cesarean section in group II was an anhydrous period of 5 days in the 22-28 weeks' gestation. Giving birth via cesarean section by women in group I was applied in $19.8 \%$ (17). Indications for cesarean section in group I were: obsessive obstetric history (the use of reproductive technologies during this pregnancy) and the weakness of labour activity no effect of its treatment $-8 \%$ (7), discoordination of labour activity - no effect of its treatment and burdened obstetric history (normal miscarriage) $3 \%$ (3), fetal distress in labour 8\% (7).

In examining the health of newborns in the early neonatal period in children with extremely low birth weight, negative prognostic factors were: the gestation term, IGH, infection, necrotizing enterocolitis. The obtained results confirm that the 5-day-long expectant management tactics of ANC makes it possible to reach the maximum probable degree of maturity of the fetal lungs with minimal risk of ascending infections in newborns. The operational delivery reduces the number and severity of IGH and necrotizing enterocolitis in newborns. Indicators of the quality of the system used in the management and delivery of women with PROM is the babies survival rate, which at 22-25 weeks' gestation improved from 20.2 to $41.1 \%$, and in the period of 26-28 weeks' gestation - from 50.2 to $87.8 \%$

So, as a result of our study, we identified the risk factors for the development of PROM with VEPL, developed a rational system of pregnancy and childbirth, which increased the incidence of newborns' survival.

Based on the objectives of our study, we summarize:

1. With the expectant management tactics of ANC of 5 days duration, there was a decrease in the number of $\mathrm{CD}^{+}-, \mathrm{CD}^{+} 6^{+}$and $\mathrm{CD} 25$ $\mathrm{CD} 25^{+}$-lymphocytes; a decrease in the content of interleukine-8, tumor necrosis factor- $\alpha$, and the enzymatic metabolism of phagocytes, especially monocytes, against the background of an increase in the functional reserve of cells. In the long anhydrous period ( $>5$ days), an increase in the signs of inflammation was observed: increased neutrophil counts, increased T-helper 


\section{Malanchuk Oleh}

cells and activated lymphocytes $\left(\mathrm{CD} 25^{+}\right)$, increased levels of serum immunoglobulins $\mathrm{A}$ and $\mathrm{M}$, and increased proinflammatory cytokines (predominantly interleukine -8), and anti-inflammatory (interleukine-10).

2. It was established a significant increase in the level of hsCRP in blood serum of women with PROM at VEPL (1.65 times) compared with the control group. An increase in the level of hsCRP (1.76-fold) in women of group I during the prolonged anhydrous period was shown, as opposed to women of the second group, in which the decrease was observed (1.58 times).

3. During the period of 22-28 weeks' gestation and PROM, an expectant management tactics of ANC lasted for 5 days with the subsequent development of women via cesarean section, the effectiveness of which was confirmed by the immunological and morphological studies of the placenta, the examination of the newborns health in the early neonatal period.

4. The expectant management tactics of 5-day-old ANC allows to achieve the maximum possible degree of maturity of the fetal lungs with a minimal risk of ascending infections in newborns. The recommended operative path of delivery gives the opportunity to reduce the number and severity of IGH and necrotizing enterocolitis in newborns. Indicators of the quality of the applied system for the management and degeneration of women with PROM is a survival index, which at of 22-25 weeks' gestation improved from 20.2 to $41.1 \%$, and at 26-28 weeks' gestation- from 50.2 to $87,8 \%$.

So we can make a conclusion, in preterm labour of 22-27 weeks' of gestation, in the case of PROM, each case requires an individual approach, and the information provided in the review may help to choose the most optimal way to help the pregnant woman to reduce the potential negative consequences for the premature newborn and improve their health.

\section{Perspectives for further research}

In the area of study of the therapy of preterm pregnancies with PROM in the period of $22-28$ weeks' gestation much research remains to be done. It needs further examination of pregnant women for the evaluation of neonatal complications. It would be of great interest for practical obstetrics to develop neonatal possibilities for taking care of new born babies who were born in the term of 22-25 weeks' gestation; special importance should be assigned to the problem of creating immunologically active components for amniotic membranes sealing in the case of their rupture. 


\section{References:}

1. Veropetvlian, P. N., Guzhevskaya, I. V., Veropetvlian, N. P. (2013) Prezhdevrennyj razryv plodovykh obolochek -infectionnyj factor [Premature rupture of membrane - infectional factor]. Zdorovje zhenshchiny, no 5 (81), pp. 57-64.

2. Holianovsky, O. V., Leush, S. S., Romanenko, T. G. (2013) Krovotechi $v$ praktytsi akushera-hinekologa [Bleeding in the practice of obstetriciangynecologist]. Kyiv: Medecyna.

3. Ivaniuta, S. O. (2012) Peredchasni polohy : [clinichna lektsia] [Premature labour : [clinical lecture]]. Neonatologia, khirurgija ta perynatalna medecyna, vol. 2, no 1(3), pp. 71-75.

4. Malanchuk, O. B. (2017). Optymisatsiya taktyky vedennia vakhitnosti ta polohiv v termini $22-28$ tyzhniv, uskladnenyh peredchasnym rozryvom plodovykh obolonok [Optimization of tactics pregnancy and delivery at 22-28 weeks of gestation, complicated by premature rupture of membranes] ( $\mathrm{PhD}$ Thesis), Kyiv: Kyiv O. O. Bohomolets National Medical University.

5. Matvienko, I. M. (2010) Povtorni anenatalni kursy kortykosteroidiv: bezpeka ta efektyvnist [Refresher corticosteroid antenatal course: safety and efficacy]. With the care to a woman, no 8 (20), pp. 27-30.

6. Moshchych, P. S., Sulima, O. G. (2004) Neonatolohija [Neonatology]. Kyiv: Vyshcha shkola.

7. Nakaz MOZ Ukrainy № 624 vid 03.11.2008. Pro vnesennia zmin do nakazu MOZ Ukrainy vid 15.12.2003 № 582 "Pro zatverdzhennia klinichnykh protokoliv z akusherskoi ta hinekolohichnoi dopomohy", nakazy MOZ vid 31.12.2004. "Pro zatverdzhennia klinichnykh protokoliv z akusherskoi ta hinekolohichnoi dopomohy" [Order of the Ministry of Health of Ukraine № 624 dated 03.11.2008 "On Amendments to the Order of the Ministry of Health of Ukraine № 582 dated 15.12.2008 "On approving clinical protocols on obstetric and gynecological aid", the Order of the Ministry of Health of Ukraine № 582 dated 31.12.2004 "On approval of clinical protocols on obstetric and gynecological aid"].

8. Nakaz MOZ Ukrayiny № 782 vid 29.12.2005 "Pro zatverdzhennya klinichnyh protokoliv z akusherskoyi ta ginekologichnoyi dopomogy". Klinichnyj protokol z akusherskoyi dopomogy "Peredchasnyj rozryv plodovyh obolonok" [the Order of the Ministry of Health of Ukraine № 782 dated 29.12.2005 "On approving clinical protocols on obstetric and gynecological aid". Clinical protocol on obstetric aid "Premature rupture of membranes".

9. Chistiakova, G. N., Gazieva, I. A., Remizova, I. I. [et al.] (2007). Otsenka tsytikinovogo profilia pri fiziologicheskoj i patalogicheski protekaiushchej beremennosti [Assessment of the cytokinins profile during physiological and pathological pregnancy]. Cytokinins and inflammation, 6 (1). - pp. 3-8.

10. Plekhanova, E. R. (2008). Prezhdevremennoe izlytie okoloplodnyh vod pri nedonoshennoj beremennosty. Taktika vedeniya beremennosti i rodov. (dissertatsia kand. med. nauk). [Premature discharge of amnionitic fluid in case with premature pregnancy. Tactics of management of pregnancy and labour] (PhD) Moscow Medical University.

11. Radzinskij, V. E., Fatkullin, I. F., Ordijants, I. M. Khamoshina, M. B. (2009). Podgotovka shejki matki k programmirovannym rodam u zhenshchin s vysokim 
perinatalym riskom [Preparation of the cervix for program delivery in women with high perinatal risk]. Farmateka, no1, pp. 53-55.

12. Krasnopolskij, V. I., Radzinskij, V. E., Bashmakova, N. V. [et al.] (2010). Podgotovka shejki matki k programmirovannym rodam. Medicinskaya tekhnologija [Preparation of the cervix for program delivery. Medical technology]. Moscow: Mediabyuro StatusPraesens.

13. Veropetvlian, P. N., Veropetvlian, N. P., Narytnik, T. T., Guzhevskaja, I. V., Zhuravleva, S. A. (2015) Prezhdevremennye rody - sovremennyj vzgliad na problemu [Premaure labour - modern view on the problem]. Woman's health no7 (103), pp. 17-22.

14. Garmajeva, E. D., Botojeva, E. A., Dambajeva, A. R. Et al. (2010) Prezhdevremennye rody [Premature labour]. Vestnik of Buriat University, pp. 143-147.

15. Prezhdevremennyi rody: clinical protokol [Premature labour: clinical protocol] (2010) Moscow: FGU “V. I. Kulakov NCAGIP” Ministry of health and social development of Russian Federation. Project Mother and child.

16. Novikova, V. A., Penzhoyan, G. A., Rybalka, Ye. Et al (2012) Rol' infektsii $\mathrm{v}$ prezhdevremennom razryve plodovykh obolochek [The role of infection in premature rupture of membranes]. Russian journal (vestnik) of an obstetrician-gynecologist, no6, pp. 35-39.

17. Simrok, V. V., Oleshko, V. D. (2014). Suchasni pidhody shchodo etiologiyi ta patogenezu peredchasnogo rozryvu plodovyh obolonok pry nedonoshenij vagitnosti (oglyad literatury). [Modern approaches to the etiology and pathogenesis of premature rupture of membranes in preterm pregnancy (literature review]. Neonatology, surgery and perinatal medicine Vol.4, 4 (14), pp. 79-86.

18. Strizhakov, A. N., Ignatko, I. V. (2007). Poterya beremennosti [Lost of pregnancy]. Moscow: MIA.

19. Chernykh, Ye. A. (2005) Rodovoj blok: rukovodstvo dlia vrachej [Birh block: Guidence for doctors]. Moscow: Triada-X.

20. Shalina, R. I., Plekhanova, Ye. R. (2007) Kompleksnaya terapiya beremennykh s ugrozoj prezhdevremennykh rodov [Complex therapy of pregnant women with a threat of premature labour]. Questions of gynecology, obstetrics and perinatology. Vol. 6, no 1, pp. 33-41.

21. Alabama Perinatal Excellence Collaborative (APEC). (2013). Guidelines: Premature Rupture of Membranes. Protocol 9, version 3.

22. American College of Obstetricians and Gynecologists; Committee on Practice Bulletins-Obstetrics 1. ACOG (2007). Practice Bulletin no. 80: Premature rupture of membranes. Clinical management guidelines for obstetriciangynecologists. Obstetrics and Gynecology, vol. 109, N 4, pp. 1007-1019.

23. American College of Obstetricians and Gynecologists; Committee on Practice Bulletins-Obstetrics. ACOG Practice Bulletin no. 127 (2012) Management of preterm labor. Clinical management guidelines for obstetrician-gynecologists. Obstetrics of Gynecology, vol. 113, N 6, pp. 1308-1317.

24. Hamilton, B. E., Minino A. M., Martin J. A. et al. (2007) Annual summary of vital statistics 2005. Pediatrics, vol. 119. pp. 345-360.

25. Brownfool, F. C., Crowther, C. A., Middleton P. (2008) Different corticosteroids and regimens for accelerating fetal lung maturation for women 
at risk preterm birth. Cochrane Database of Systematic Reviews, vol. 46. Art. N CD006764.

26. Bruant, M. P., Phenning, N., Holt, J.G. (1989) Bergey's manual of systematic bacteriology. Baltimore: Williams and Wilkins.

27. Carroll S., Knowles, S. (2013) Clinical practice guideline: preterm prelabour rupture of the membranes. (Institute of Obstetricians and Gynaecologists, Royal College of Physicians of Ireland and Directorate of Strategy and Clinical Care, Health Service Executive), Version 1.0. Guideline N 24.

28. Le Ray, I., Mace, G., Sediki M et al. (2014) Changes in Maternal Blood Inflammatory Markers as a Predictor of Chorioamnionitis: A Prospective Multicenter Study. American Journal of Reproductive Immunology. Article first published online. - DOI: 10.1111/aji.12323.

29. Shatrov, J. G., Birch, S. C., Lam, L.T. et al. (2010) Chorioamnionitis and cerebralpalsy: a meta-analysis. Obstetrics and Gynecology, vol. 116, no 2, pt 1, pp. 387-392.

30. Cobian-Sanchez F. F., Thilaganathan, Prefumo, A., Bhide, B. (2004) Secondtrimester uterine artery Doppler and spontaneous preterm delivery. Ultrasound in Obstetrics and Gynecology, no 4, pp. 435-439.

31. Mercer, B. M., Petraglia, F., Strauss, G. F. et al.Complicated Pregnancy [4th ed.]. London: Informa health care.

32. Cunningham F., (2014) Williams Obstetrics. New York: McGraw-Hill Education pp. Chapter 23: Abnormal Labour ISBN 978-0071798938.

33. Di Renzo, G. C., Roura, L. C., Facchinetti, F. (2011) The EARM - study Group on "Preterm Birth". Guidelines for the management of spontaneous preterm labour, identification of spontaneous preterm labour, diagnosis of preterm premature rupture of membranes, and preventive tools for preterm birth. The Journal of Maternal-Fetal and Neonatal Medicine, vol. 24 (5), pp. 659-667.

34. Dowswell, T., Kelly, A. J., Livio, S. et al (2010). Different methods for the induction of labour in outpatient settings. Cochrane Database of Systematic Reviews., Iss. 8. Art. N CD007701.

35. Devlieger, R., Millar, L. K., Bryant-Greenwood, G. et al. (2006) Fetal membrane healing after spontaneous and iatrogenic membranerupture: a review of current evidence. American Journal of Obstetrics and Gynecology, vol. 195, no 6, pp. $1512-1520$.

36. Hofmeyr, G. J. (2000) Amnioinfusion for preterm rupture of membranes. Cochrane Database of Systematic Reviews, Iss. 2. no CD 000442.

37. Hösli. Irene (2014) "Tocolysis for preterm labour: expert opinion". Arch Gynecol Obstet. 289: 903 - 909. doi: 10.1007/s00404-01303137-9. PMID 24385286.

38. Sciscione, A. C., Manley, J. S., Pollock, M. et al. (2001) Intracervical fibrin sealants: a potential treatment for early preterm premature rupture of the membranes. American Journal of Obstetrics and Gynecology, vol. 184, pp. 368-372.

39. Kazzi, G. M., Bottoms, S. F., Rosen, M. G. (1982) Efficacy and safety of Laminaria digitata for preinduction ripening of the cervix. Obstet. Gynecol., 60 (4), pp. $440-443$.

40. Kim, S. H., Chang, Y. H. Kim, W.K. et al. (2003) Two cases of anaphylaxis after laminaria insertion. J Korean Med. Sci., 18(6):886-888. 
41. Knowles, S. R., Djordjevic, K., Binkley, K., Weber, E. A. (2002) Allergic anaphylaxis to Laminaria. Allergy, 57 (4):370.

42. Leigh Ann Anderson (Ed), Judith Stewart, Philip Thornton et al (2017, October 9). Laminaria. Medically reviewed on October, 9 2017. - www.drugs.com

43. Lin, S. Y., Chang, W. F., Su, Y. N., Chen, C. A., Lee, C. N. (2006) Septic shock after intracervical laminaria insertion. Taiwan J. Obstet. Gynecol, 45 (1), pp. 76-78.

44. Doyle, L. W., Crowther, C. A. Middleton, P. et al. (2009) Magnesium sulphate for women at risk of preterm birth for neuroprotection of the fetus. Cochrane Database of Systematic Reviews, Iss. 1. N CD004661.

45. Popowski, T., Goffinet, F., Maillard, F. et al. (2011) Maternal markers for detecting early-onset neonatal infection and horioamnionitis in cases of premature rupture of membranes at or after 34 weeks of gestation: a two-center prospective study. BioMed Central Pregnancy \& Childbirth, vol. 11, pp. 26.

46. Mozurkewich, E. L., Chilimigras, J. L., Berman, D. R. et al. (2011) Methods of induction of labour: a systematic review. BioMed Central Pregnancy and Childbirth, vol. 11, pp. 84.

47. Mohr, T. (2009) Premature rupture of the membranes. Gynecological Endocrinology, vol. 5, no 1, pp. 28-36.

48. Ogunyemi, D., Trompson, W. (2002) A case controlled study of serial transabdominal amnioinfusion in the managament of second trimester oligohydramnion ane to premature rupture of membranes. European Journal of Obstetrics and Gynecology Reprodiction Biology, vol. 102, pp. 167-172.

49. "Practice Bulletins No. 139" Obstetrics \& Gynecology. 122 (4): 918-930. October 2013. doi: 10.1097/01.AOG.0000435415.21944.8f.PMID 24084566. Retrieved 12 November 2014.

50. Frenette, P., Dodds, L., Armson, B. A., Jangaard, K. (2013) Preterm Prelabour Rupture of Membranes: Effect of Latency on Neonatal and Maternal Outcomes. Journal of Obstetrics and Gynecology of Canada, vol. 35, no 8, pp. 710-717.

51. McKinlay, C. J., Crowther, C. A., Middleton, P., Harding, J. E. (2012) Repeat antenatal glucocorticoids for women at risk of pretermbirth: a Cochrane Systematic Review. American Journal of Obstetrics and Gynecology, vol. 206, no 3, pp. 187-194.

52. Crowher, C. A., Mc Kinlay, C. J., Middleton, P., Harding, J. E. (2011) Repeat doses of prenatal corticosteroids for women at risk of preterm birth for improving neonatal health outcomes. Cochrane Database of Systematic Reviews. Iss. 6. N CD003935.doi.10.1002/14651858.CD003935.pub3.

53. Roberts, D. (2006) Amnioinfusion in preterm premature rupture of membranes (AMIPROM) study. Liverpool Women Hospital NHS Trust. ISRCTN N 81932589.

54. Roberts, D., Dalziel, S. (2006) Antenatal corticosteroids for accelerating fetal lung maturation for women at risk of preterm birth. Cochrane Database of Systematic Reviews. Iss. 3. N CD004454.

55. Kendal-Wright, C. E., Hubbard, D., Gowin-Brown, J., Bryant-Greenwood, G. D. (2010) Stretch and inflammation-induced Pre-B cell colony-enhancing factor (PBEF/Visfatin) and Interleukin-8 in amniotic epithelial cells. Placenta, vol. 31, no 8, pp. 665-674. 
56. Tavassoli, F., Ghasemi, M., Mohamadzade, A., Sharifian J. (2010) Survey of Pregnancy Outcome in Preterm Premature Rupture of Membranes with Amniotic Fluid Index $<5$ and $\geq 5$. $O M J$, vol. 25. - P. 118-123.

57. Park, J. S., Yoon, B. H., Romero, R. et al. (2001) The relationship between oligohydramnios and the onset of preterm labor in preterm premature rupture of membranes. American Journal of Obstetrics and Gynecology, vol. 184, no 3, pp. $459-462$.

58. Gojnic, M., Fazlagic, A., Pervulov, M. et al. (2005) The significance of C-reactive protein in the diagnosis of fetal tachycardia and therapy of chorioamnionitis. Clinical and Experimental Obstetrics and Gynecology., vol. 32, no 2, pp. 114-116.

59. Doyle, L. W. Crowther, C. A., Middleton, P. et al. (2011) Tocolytics for preterm premature rupture of membranes. Cochrane Database of Systematic Reviews. Iss. 10: CD007062. doi: 10.1002/14651858.CD007062.pub2.

60. Tranquilli, A. L., Ginnbilo, S. R., Bezzeccheri, V., Scagnolic, C. (2005) Transabdominal amnioinfusion in preterm premature rupture of membranes: a randomized controlled trial. Bjog, vol. 112, pp. 759-763.

61. De Sants, M., Scavvo, M., Noia, G. et al. (2003) Transabdominal amnioioinfusion treatmtnt of severe oligohydramnions in preterm premature rupture of membranes less than 26 gestational weeks. Fetal Diagnosis and Therapy, no 18., pp. 412-417. 